\title{
The Risk Dilemma
}

\author{
Michael Walzer ${ }^{1}$
}

Received: 22 October 2015 / Accepted: 22 April 2016/

Published online: 29 July 2016

(C) Springer Science+Business Media Dordrecht 2016

My talk today is focused on two questions. The first is, how should we fight against insurgents/terrorists who hide among, and attack from the midst of, the civilian population? And answering that question leads immediately to another, which is also the core issue, the issue that makes everyone nervous: how much risk must our soldiers take to reduce the risks they impose on civilians when they respond to those attacks?

These are questions for both Americans and Israelis - they were raised in Israel in the debates that followed the Gaza war and in the US in the ongoing debates about the rules of engagement in Afghanistan. They are moral questions but also political questions, because the number of civilian deaths is a major factor in determining both in-country and international judgments about the legitimacy of the war. The insurgents don't hide only to protect themselves, as the phrase "human shields" suggests; they hide in order to expose the civilian population to attack. They believe that civilian deaths work to their advantage, and they are probably right. It is this prospect of insurgent advantage that has dominated American decision-making in Afghanistan.

About a year ago, I visited the Army War College in Carlyle, Pennsylvania, to lecture about what's now called "asymmetric warfare" (war between a modern army and a guerrilla band or a terrorist organization; high tech against low tech) - I focused then on the 2006 Lebanon war and defended and criticized Israel's conduct of that war. I also had a chance to talk with a group of colonels just back from Afghanistan, where they were reviewing and revising the rules of engagement - a necessary task because we were killing too many Afghan civilians and, partly because of that, losing the political war. Not only because of that: we were (and are) losing the war because we are fighting in a foreign country whose culture we don't understand very well, on behalf of a radically corrupt and ineffective government. Still, the death of Afghan civilians at our hands was and is a critical issue.

Michael Walzer

walzer@ias.edu

1 School of Social Science, Institute of Advanced Study, Princeton, NJ, USA 
One of the colonels described a typical battlefield dilemma (with which IDF soldiers will be familiar): Imagine a group of Taliban militants on the roof of a small apartment building in an Afghan town, firing at American soldiers. The soldiers are unsure who is in the building - possibly a family or several families, who may be locked in or, maybe, they just have no place to go. What are the soldiers' options? They can pull back and call in an air strike - as American soldiers have done too often in the past; they can try to get some soldiers closer to the building, or into the building, or onto an adjacent roof, so as to aim directly at the militants; or they can simply disengage, which means leaving the battlefield to the enemy. The colonel argued that sometimes, when getting closer to the building was impossible or too risky, disengagement was the right choice - even though this goes against the standard US army doctrine that you never willingly leave the battlefield to the enemy. But, he said, it's better in cases like this to avoid civilian casualties, and there would be other chances to get the bad guys on the roof. And then, turning to me, knowing my obsession with Israel's wars, he said "We don't have to worry about a ceasefire; we can fight a slow war..." There really will be more chances, he said, to engage the Taliban militants.

The colonel meant to express sympathy for Israel, which often doesn't have similar options, and it was comforting to realize that at this level, among officers in the field, the sense of a common enemy, a common task, and common problems with that task, was very strong. But the contrast is real. In its wars, Israel is always confronted by a looming ceasefire, therefore is always fighting a fast war, and that is more dangerous for civilians. Note another difference between Israel's wars and America's: if we kill civilians in Afghanistan, it makes success in Afghanistan harder, but it doesn't cause a great deal of fuss at home, and the rest of the world is, not entirely but mostly, indifferent. If Israel kills civilians, there are fierce debates in Israel, and the rest of the world is quick with its condemnation. So it's an especially important question for Israelis: how should their soldiers fight? Especially important also, of course, because the soldiers are everybody's children, which isn't true these days in the US.

Israel's enemies and America's-let's say, for now, Hamas and Taliban militants-hide among the civilian population, effectively using civilians as cover. So if the IDF or the US Army attacks them, and kills civilians, isn't it their (Hamas's/the Taliban's) responsibility? The IDF and the US Army should avoid collateral damage if they can, fighting with as much precision as they can manage, but damage to human shields isn't "collateral" in the usual sense. These people aren't disengaged from the business of war; they have been conscripted, and if they are killed, their deaths are on the heads of the people who conscripted them, the people who are using them.

But that's only partly right; it isn't, it can't be, the whole story, as we will see if we begin by thinking about symmetric warfare, about the usual forms of combat and the usual meaning of collateral damage - where the issues are different, but not all that different. Consider an example from World War Two (a symmetric war, between organized armies): the target of an attack by the British air force is a German tank factory located in a working class neighborhood. The factory hasn't been put there to take advantage of civilian cover; that's where factories were built before workers had cars. So how should the British attack? A certain number of civilian deaths, let's say, is "not disproportionate" to the value of destroying the factory and stopping the production of tanks for the German war effort. The number might get pretty high, since the value is pretty great. But there still are choices: the British pilots can fly by day or night 
(they will kill more civilians at night but lose fewer planes); they can fly at high or low altitudes (they will kill more civilians at high altitudes, but, again, lose fewer planes).

Moral philosophers can't determine these choices, but there is a strong moral argument that soldiers should accept some risk in order to minimize the risks to civilians. The civilians may include supporters of the Nazis, but they also include opponents, and people without any political commitments at all, and then there are the children "who don't know their right hand from their left" (as God told the prophet Jonah about the inhabitants of Nineveh). "Some risk" has been pretty much the accepted rule - often honored in the breach, but also often honored (the US Air Force flew by day in World War Two, accepting greater risks in order to aim more accurately). When I visit the military academies at West Point and Annapolis, I am regularly told that "some risk" is necessary-morally necessary, but also a central feature of the professional code.

Minimizing civilian deaths is a matter of "honor" as well as morality.

Now, how different is the tank factory story from the stories we hear every day from Afghanistan? It makes some difference if civilians are deliberately being used (and deliberately exposed) - there is a shift of responsibility toward the militants who are using them, and away from the soldiers who may be killing them. There may be a discounting of civilian lives in the proportionality calculations, so that we don't encourage the future use of human shields. But there must also be a serious effort to minimize civilian casualties, so that we don't encourage the continued exposure of civilians. In any case, the soldiers can't be entirely free of responsibility - because they are moral and military agents, and they have choices to make about how they will organize the attack.

That they aren't entirely free is now official US Army doctrine. Gen. McCrystal, the US commander in Afghanistan until he spoke too freely to reporters, issued a set of rules of engagement that require soldiers to accept risks in order to avoid killing civilians. And Gen. Petreus, his successor, reaffirmed the rules, despite protests reported in the US press from soldiers on the ground. I should say, from some soldiers on the ground, who talked to reporters; I don't know how the rules are actually experienced and how they are observed (or ignored) by American combat troops.

Two Israelis, a professor and a general, Asa Kasher and Amos Yadlin, have been writing articles (first, I think, in US journals) and speaking at meetings in Israel arguing that soldiers should take no risks to protect civilians in situations like the ones I have been describing, where the civilians are not under their control and protection. Proportionality and necessity are sufficient restraints; beyond those two, enemy civilians have no claim on our soldiers, who can put their own lives first in whatever calculations the battle imposes. In response to Kasher and Yadlin, Avishai Margalit and I published an article in Haaretz (and after that in the New York Review of Books) arguing that "some risk" is morally required. I am told that the issue is very much in dispute here in Israel. I've also been told that in the Gaza war different units of the army fought in accordance with different rules or, better, with different understandings of the same rules. I suspect that the same thing is happening in Afghanistan - a lot depends on the junior officers in the field and on how they interpret the new rules of engagement.

Kasher has argued that it is right, even morally necessary, to warn civilians of coming attacks, and he has cited the thousands of phone calls that Israel made to civilians in Gaza, telling them to get out of their homes before the planes or artillery 
strike. This is surely a good thing to do, even though it also warns the militants to get ready for an attack and so might (marginally) increase the risks that attacking soldiers will face. But the American experience with free-fire zones in Vietnam suggests that warnings are not effective or not effective enough: many people don't leave, because they are old or sick, or because they are caring for relatives who are old or sick, or because they are afraid that their homes will be looted, or because they have no place to go - or because they are held in place by the insurgents, who want their cover and who will benefit from their deaths.

So, what should we do?

I doubt that this question is best addressed in the language of human rights and war crimes - the way the Goldstone Report addresses it (with reference to Gaza, of course, not Afghanistan). Civilian have a right not to be deliberately targeted-we call targeting civilians "terrorism," and that certainly is a violation of human rights and a criminal activity. But how to deal with a civilian population that is being used as cover - that requires a more nuanced analysis. Remember: this population includes Hamas or Taliban supporters, Hamas or Taliban opponents, people who are desperately trying to avoid choosing sides, and (a third to half of them) children.

"Some risk" seems to me the necessary position when we are dealing with insurgents using civilian cover. It is both morally and politically required. Morally required for the scared: these are, all of them or most of them, innocent people, unarmed and frighteningly vulnerable, and the soldiers are armed and trained to fight and to protect themselves and each other-and it is the soldiers who are actively imposing the risk. Politically required because it's the aim of militants who hide among civilians to force their enemies to kill large numbers of civilians - and we are not going to win the battle against the militants by doing what they want us to do.

I need to stress that the issue here is not the protection of enemy civilians, as it is often described. The enemy has an obligation to protect its own civilians, which in these cases it obviously isn't doing. We have an obligation to protect our civilians - and to rescue them when they are in trouble, as Israel did when it sent commandos to Entebbe. Had the Entebbe hostages been Swedes, say, Israel would have had no obligation to rescue them. The obligation I am talking about here isn't to protect or rescue foreign or enemy civilians but to avoid killing them, if that is possible, and for the sake of that avoidance, soldiers will sometimes have to accept risks to themselves. As I've already said, I don't think that philosophers can say anything very precise about how much risk-taking is necessary. We can't say that the answer is 9 or 17 or 33. These are decisions that soldiers have to make, within a set of guidelines (the rules of engagement) and after having been trained to fight in accordance with those guidelines. The training is important. As a former Israeli soldier said to me, it is incompetence and inexperience that breeds brutality.

In Afghanistan, some American soldiers have told reporters that McCrystal's rules of engagement are too risky for them. On the other hand, I have talked to American and Israeli soldiers who firmly believe that taking risks to minimize civilian casualties is part of their job. It is crucial to the pride they take in doing their job.

But to what extent is this their job? Taking risks to save lives is required in certain professions - it is a central feature of the fireman's professional code, for example, and this is true whether the people at risk are citizens or foreigners, relatives, friends, or personal enemies. But rescuing people trapped in burning buildings is the most 
important job of the fireman. The military profession is different. The most important job of the soldier is to win the war or to accomplish a military mission that is closely connected to winning the war. It is commonly taken for granted that some number of civilian deaths is "not disproportionate" to the value of that mission. We want soldiers to minimize that number as best they can, even at some risk to themselves. But the risktaking can't undermine or endanger the mission. This military target is so important (we believe) that we will allow some collateral damage in order to capture or destroy it.

Militants who hide among civilians increase the likely collateral damage and-this is where I started - the responsibility for that increase falls on them. But, again and still, civilians used as cover aren't entirely different from civilians who just happen to live near a military target: they are, so to speak, the same people. The soldiers are imposing risks on these people; they are capable of fighting in ways that reduce the risks; they should do that.

They have to strike some sort of balance between military effectiveness and moral decency - and many/most soldiers want to do this. They don't think of themselves as killers of children; that's not good for morale. Striking the balance is harder to do when civilians are used as cover, and the balance may be struck in a different place: that is a critically important point that the Goldstone Report ignored. The biggest failure of Judge Goldstone and his colleagues was their refusal to engage with the difficulties of asymmetric warfare, to think seriously about the choices soldiers have to make. But soldiers still have to make those choices, even when lawyers ignore their difficulty.

In a recent article in The New Republic, Amitai Etzioni argued against the McCrystal rules of engagement. We should avoid wars like Afghanistan, or refuse to fight them on the ground, he said, but if we have to fight them, we should fight without restraining (and endangering) our own soldiers. He is certainly right about avoiding these kinds of wars if we can. But if we can't, we have to fight with moral discipline. That means taking care and taking risks to minimize civilian casualties. That is better for civilians, obviously, but it is also better for our own soldiers, because a demoralized army isn't a good army-moral discipline is closely related to all the other forms of discipline that make an effective fighting force. Maintaining moral discipline may be especially difficult in asymmetric warfare. I don't want to be too quick to say that it will pay off politically and militarily, though I think it will. It is also important for its own sake. We have moral reasons to act morally. 